\title{
Applied Undergraduate College Students' Innovative Entrepreneurship Education Problems and Countermeasures*
}

\author{
Laihu Li \\ Baicheng Normal University \\ Baicheng, China
}

\begin{abstract}
With the deepening of the economic system reform and the rapid development of the market economy, China has set off a frenzy of national entrepreneurship. It is the requirement of the times to carry out innovative entrepreneurship education for college students, and it plays an important role in improving their entrepreneurial ability and innovative thinking. However, under the constraint of the traditional school idea, many application-oriented undergraduate colleges and universities have not done well in innovation and entrepreneurship education, and there are still many problems. From these problems, this paper discusses the countermeasures to solve the problems.
\end{abstract}

Keywords-application-type; undergraduate institutions; university students; innovation and entrepreneurship education

\section{INTRODUCTION}

Many college students have a great passion for entrepreneurship, but entrepreneurship is not as simple as walking. Many entrepreneurial failures have bloody lessons to tell people: blind entrepreneurship will surely lead to failure. Entrepreneurship requires appropriate projects, appropriate platforms, and certain innovative ideas. Without these elements, it is doomed to failure. Whether college students start their own business or take up employment in the future, they should have the corresponding sense of entrepreneurship and innovative thinking. Therefore, applied undergraduate colleges should start from college students and carry out innovative entrepreneurship education.

\section{THE PRACTICAL SIGNIFICANCE OF INNOVATION AND} ENTREPRENEURSHIP EDUCATION FOR COLLEGE STUDENTS

\section{A. Self-development Needs of University Students}

Innovation and entrepreneurship stress has become the consensus of the whole people, and it is an urgent need for the development of the times to strengthen the innovation and entrepreneurship education of college students. Due to the lack of work experience and industry spirit, many college students can't find suitable jobs after graduation and will

*Fund: This paper is the phased achievement of the 13th Five-year Educational Science Research Project of the Jilin Province; Research on Innovation and Entrepreneurship Education for College Students in Application-Oriented Universities. choose the road to entrepreneurship. College students are very willing to engage in entrepreneurship in related industries and apply the knowledge they have learned in innovation and entrepreneurship to physical operations in order to achieve personal value and self-development. The innovation and entrepreneurship education of applied colleges and universities is based on professional knowledge, teaching students innovation and entrepreneurship, and providing corresponding platforms for their innovation and entrepreneurship practices, improving their innovation and entrepreneurship capabilities. This is an important part of the future education of applied colleges and universities.

\section{B. Effective Access to Employment for University Students}

Since the implementation of the university enrollment expansion policy, the number of university graduates has continued to increase, which has brought great pressure on social employment. Applied colleges and universities carry out innovation and entrepreneurship education, and encourage and guide college students to innovate and start their own businesses. This is conducive to improving the comprehensive quality of college students and laying a theoretical and ability foundation for their future social challenges. Supporting and encouraging college students' innovation and cultivating their innovative entrepreneurship spirit is the embodiment of the applied universities' transformation of employment education into entrepreneurial education thinking. It is also an effective way to promote employment in application-oriented undergraduate colleges to promote employment by starting a business and turning college students from job seekers into creators.

\section{Employers' Requirements}

Nowadays the competition of enterprises is the competition of talents. Enterprises must continue to gain more economic benefits and remain invincible in the fierce market competition. Localities must constantly innovate in products and services, and innovation requires talent. Nowadays, many enterprise human resources management departments pay great attention to the comprehensive quality of college students 'innovation and entrepreneurship when they recruit people. Therefore, application-oriented undergraduate colleges must strengthen the innovation and 
entrepreneurship education of college students in order to meet the needs of talents for enterprise development. [2]

\section{Transformative Development Needs}

The traditional applied undergraduate colleges only apply professional theoretical knowledge to college students, and they cannot get a place in their innovative entrepreneurship education, so that it is difficult for college students to adapt to the rapid development of the social economy after graduation. Against the background of the continuous improvement of the market economy with Chinese characteristics, all walks of life are striving to seek transformation, and application-oriented undergraduate colleges and universities need to take it as their main task. Its core lies in strengthening students 'innovation and entrepreneurship education.

\section{E. The Need to Improve School Competitiveness}

At present, most schools haven't yet set up innovative entrepreneurship education courses, or the courses that have been set up haven't formed a complete curriculum system, and they haven't done enough in terms of entrepreneurship practice education. Applied undergraduate colleges and universities can effectively promote the development of innovation and entrepreneurship education if they integrate innovation and entrepreneurship education into professional education research and professional personnel training; thus it is needed to improve the competitiveness of the school in similar universities and attract more outstanding students to study in the school.

\section{PROBLEMS IN INNOVATION AND ENTREPRENEURSHIP EDUCATION IN APPLIED UNDERGRADUATE COLLEGES}

\section{A. Some Institutions Haven't Paid Attention to It}

Many application-oriented undergraduate colleges don't have a deep understanding of the essence of innovation entrepreneurship education. They believe that the school's innovation entrepreneurship education is only an optional task for college students' employment guidance, but only to cultivate entrepreneurs. This kind of incorrect concept leads to innovation and entrepreneurship education teachers neglect the cultivation of innovation and entrepreneurship consciousness of college students, and only teach entrepreneurial knowledge and skills, to a certain extent, the comprehensive quality of college students in innovation and entrepreneurship is not high. Some students think that after graduation, they directly go to work in enterprises and there is no need for innovative entrepreneurship education. Therefore, they don't pay enough attention to innovative entrepreneurship education and are reluctant to actively participate in entrepreneurial activities organized by schools.

\section{B. The Educational Model Is Still Under Exploration}

The applied undergraduate colleges and universities have not formed a unified model of innovation and entrepreneurship education. The innovation and entrepreneurship education of each university is based on its own understanding and carries out innovation and entrepreneurship education according to its own resources This has caused the innovation and entrepreneurship education model of various institutions to be imperfect, the education level is uneven, which is not conducive to the development of innovation and entrepreneurship education, and is not conducive to the training of innovative and entrepreneurial talents. [3]

\section{Inadequate Curriculum System}

Many application-oriented undergraduate colleges haven't yet set up innovative entrepreneurship education courses. Although some colleges and universities have carried out innovative entrepreneurship education, their teaching methods are single, mainly lecture-style teaching. The course subjects are also single. They are only the basic understanding and simple exploration of innovative entrepreneurship education by university teachers. There are no other auxiliary courses that are closely related to innovation and entrepreneurship. In addition, there is a lack of effective guidance on practical entrepreneurship education. This situation makes the content of innovation and entrepreneurship education very fragmentary, and doesn't form a perfect curriculum system, which leads to the increase of learning difficulties for college students and can't achieve the expected teaching goals.

\section{De-linking Innovative Entrepreneurship Education from Professional Education}

At present, most of the innovative entrepreneurship education conducted by applied undergraduate institutions is separated from their own professional education, but some innovative entrepreneurship courses are inserted into the original professional curriculum system and are not related to professional courses. This form of education doesn't take into account the close correlation between professional education and innovative entrepreneurship education. If innovation and entrepreneurship education is separated from professional education, it will become a source of water. Without innovation and entrepreneurship education, it will not improve the comprehensive ability of college students in innovation and entrepreneurship. If the two are not matched, innovation and entrepreneurship education will not achieve the purpose of education, and thus becoming a form.

\section{E. Lack of Practical Education}

Practice is the only criterion to test the truth. It is not only for college students to learn the knowledge of innovation, but also to apply the knowledge to practice. Entrepreneurship practice education is an important part of innovation entrepreneurship education, and it is also an important link to test the results of innovation entrepreneurship education. However, at present, many application-oriented undergraduate colleges and universities mainly focus on theoretical knowledge teaching and lack of entrepreneurial practice education. Due to various conditions, although some institutions have carried out entrepreneurial practice education, the level is too low and the participation of students is not high. The lack of real entrepreneurial 
experience of college students is very unfavorable to the improvement of their innovation and entrepreneurship ability.

\section{F. Lack of Teaching Staff}

The teaching of innovation and entrepreneurship education in application-oriented undergraduate colleges needs corresponding teaching staff to carry out. Innovation and entrepreneurship education teachers should have the corresponding theoretical knowledge and the ability to carry out theoretical research, but also have experience of entrepreneurship practice. However, in reality, the teachers of innovation and entrepreneurship education in practical colleges and universities are all part-time teachers of other majors in the school, and there is no systematic research on the theory of innovation and entrepreneurship. And in the practice of entrepreneurship, there are many innovations.

\section{MEASURES TO STRENGTHEN INNOVATION AND ENTREPRENEURSHIP EDUCATION IN APPLIED UNDERGRADUATE COLLEGES}

\section{A. Development of a Sound Curriculum System}

Applied undergraduate colleges and universities must first clearly carry out the purpose of innovative entrepreneurship education, which is also the basis for the establishment of innovative entrepreneurship curriculum. At present, the requirements of the society for university graduates are getting higher and higher. Applied undergraduate colleges and universities should formulate innovative entrepreneurship courses in accordance with the needs of society and the development requirements of corresponding professional students, integrate innovative entrepreneurship education into professional education, and cultivate talents with innovation and entrepreneurship consciousness and higher professional qualities for the society

At the same time, the advanced teaching model should be used, and college students should actively participate in the classroom teaching of innovation and entrepreneurship education, so as to improve the teaching effect. In addition, the innovation and entrepreneurship curriculum should be set up in line with the international standards and meet the needs of the development of the times.

Applied undergraduate colleges and universities should incorporate innovation courses into the general curriculum system of universities, actively explore new teaching models of innovative entrepreneurship education, and based on the school's own conditions, divide them into theoretical courses and practical courses, and establish a complete innovation and entrepreneurship curriculum system. [5]

\section{B. Construction of Long-acting Operating Mechanisms}

Many application-oriented undergraduate colleges and universities have not established a perfect innovation and entrepreneurship education platform, so that innovation and entrepreneurship education lacks effective protection. Therefore, colleges and universities should establish a sound innovation and entrepreneurship education mechanism, set up a special research department, carry out the implementation and management of innovation and entrepreneurship education, thus forming a systematic and standardized management platform.

On the other hand, applied undergraduate colleges should incorporate innovation entrepreneurship education into the school performance assessment system as an institutional guarantee for innovation entrepreneurship education. At the same time as carrying out innovation and entrepreneurship education, people will examine the quality of teaching, establish a sound system for evaluating the quality of innovation and entrepreneurship education, evaluate all aspects of teacher teaching, and adjust teachers' performance wages according to the results of the evaluation. Therefore, the teaching quality of teachers who can innovate entrepreneurship education can be improved.

\section{Strengthening the Teaching Staff}

Innovation and entrepreneurship education involves many fields, and it is an education for students comprehensive quality. This requires the establishment of a diversified teacher structure for innovation and entrepreneurship education. The content of innovation and entrepreneurship education covers multiple areas of knowledge such as venture capital, financial management, and engineering technology. The development of teaching needs to bring together teachers from these related majors to form a special innovation and entrepreneurship education team. Therefore, the primary task is to train a group of innovative entrepreneurship education teachers who have both theory and practice.

\section{Encouraging Students to Practice Entrepreneurship Through Competitions}

Applied undergraduate colleges hold competitions related to innovation and entrepreneurship education, and set up generous rewards, which can greatly stimulate college students' enthusiasm for innovation and entrepreneurship. The most lack of today's society is innovative talents, and some college students will lose their creative motivation due to certain factors. And the form of competition can better stimulate the innovative entrepreneurial spirit of college students.

The content of the competition can cover entrepreneurial projects, marketing activities, etc. Applied undergraduate colleges and universities can also organize joint ventures to hold more influential competitions so that participating college students understand the importance of the competition and the advantages of their own development. At the same time, in terms of competition prizes, it can be a title or qualification awarded by the school or the company, or it can be a generous bonus to enhance the attractiveness of college students.

\section{E. Intensifying the Expansion of the Practice Base}

One of the main courses of innovation and entrepreneurship education is to carry out entrepreneurship practice education. At present, many application-oriented 
undergraduate colleges and universities have established entrepreneurship practice bases within the school. However, due to the limitations of various resources in universities, further development is needed in terms of operation management, hardware and software facilities, and so on. There are many problems that make the use of the entrepreneurial practice base less than ideal, and it cannot fully play the actual role of innovation entrepreneurship education.

The internal practice base established by the applicationoriented undergraduate colleges obviously cannot meet the actual needs of college students' entrepreneurial practice. Therefore, people should expand the practice base of innovation and entrepreneurship education into the society, make full use of various resources in the society, combine the advantages of the institutions themselves, and explore new models of entrepreneurship and entrepreneurship education such as cooperation between schools and enterprises, production, research and development so as to provide sufficient guarantees for college students to practice outside the school to enable them to gain real social entrepreneurship experience.

\section{F. Improving the System of Guarantee for Students' Entrepreneurship}

Many college students stay away from entrepreneurship, mainly because of the lack of innovative entrepreneurship education or the lack of entrepreneurial resources (funds, projects, etc.). These factors have caused them to lose their motivation to innovate. In addition to cultivating the innovation and entrepreneurship ability of college students, application-oriented undergraduate colleges should also provide necessary financial support for college students' innovation and entrepreneurship.

Applied undergraduate colleges and universities should set up special funds for innovation and entrepreneurship, and establish a sound management mechanism. Schools were limited in strength and should make full use of off-campus resources. First of all, application-oriented undergraduate colleges and universities should include the relevant start-up subsidies issued by the state into the special funds for innovation and entrepreneurship. Secondly, in cooperation with the social welfare projects, people will strive for subsidies for the innovative entrepreneurial activities of college students. Thirdly, the school should aim at the college student entrepreneurship project, actively contact the relevant investors, and provide relevant resources for the college student's innovation and entrepreneurship development. In addition, the innovation and entrepreneurship education of applied undergraduate colleges in China has just started, and it is still far from the advanced countries in the west. It is necessary to learn from their knowledge and experience in order to promote greater progress in innovation and entrepreneurship education.

\section{CONCLUSION}

Innovation and entrepreneurship education will be of great help to college students in their future employment and entrepreneurship. Applied undergraduate colleges and universities should increase their investment in innovation and entrepreneurship education, build their own institutional characteristics, devote themselves to cultivating talents with strong comprehensive quality, and make greater efforts to ease the employment pressure of college students and promote their effective entrepreneurship and employment.

\section{REFERENCES}

[1] Yangnuo. On the Scientific Connotation and Significance of Innovation and Entrepreneurship Education in Colleges and Universities [J]. Electronic World, 2014(10): 228

[2] Wufangpeng. Problems and Countermeasures of Innovation and Entrepreneurship Education for Students in Applied Undergraduate Colleges [J]. Journal of the Wuhan Business University, 2015, 29(3): 81-84.

[3] Ding Bo, Ye Shujiang, Pu Ming. Research on the Problems and Countermeasures of Innovative Entrepreneurship Education in Applied Undergraduate Colleges [J]. Journal of Heilongjiang Institute of Education, 2012(5): 10-11.

[4] ZhaoYang. Problems and Countermeasures of Applied Undergraduate Innovation and Entrepreneurship Education [J]. Logistics Engineering and Management, 2014(1): 230-232.

[5] Li Na. Problems and Countermeasures of Innovation and Entrepreneurship Education in Applied Undergraduate Colleges [J]. Shandong Trade Union Forum, 2015(3): 131-132. 